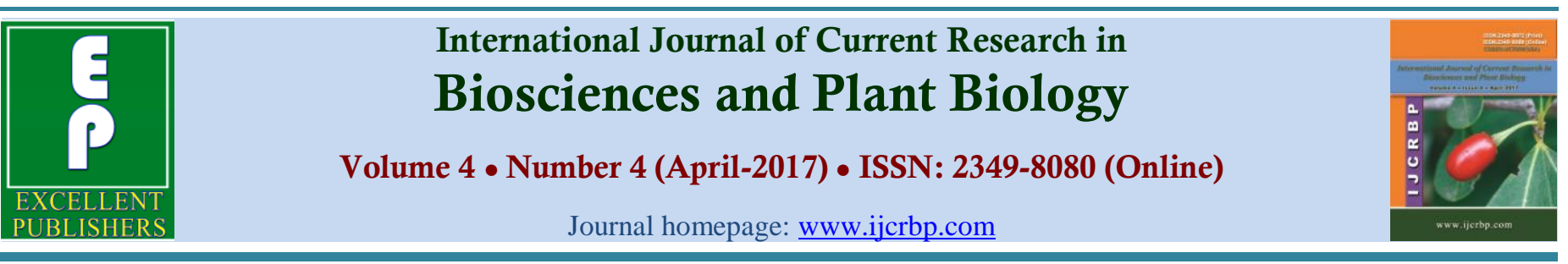

\title{
Assessment for the Incidence of Number of Subcultures on Genotype Stability for In Vitro Plantlets of Yam (Dioscorea spp.) Using RAPD Markers
}

\author{
Arnaud Agbidinoukoun ${ }^{1 *}$, Antoine Abel Missihoun ${ }^{1}$, Pierre Akonde ${ }^{2}$, Hurbert Adoukonou Sagbadja ${ }^{1}$, \\ Clément Agbangla ${ }^{1}$ and Corneille Ahanhanzo ${ }^{1}$
}

${ }^{1}$ Department of Genetic and Biotechnology, Faculty of Science and Technology, University of Abomey-Calavi, 01 BP 526,
Cotonou, Republic of Benin
${ }^{2}$ Institut National de Recherche Agronomique du Bénin (INRAB), Cotonou, Republic of Benin

*Corresponding author.

\begin{tabular}{|c|c|}
\hline Abstract & Article Info \\
\hline \multirow{8}{*}{$\begin{array}{l}\text { The impact of the number of subcultures on the stability of yam genotype maintained in } \\
\text { in vitro genebank was investigated. Six accessions of yam (Ala, Bagri Kogan, Kokoro, } \\
\text { Sossou, and Tankpanou), belonging to the complex Dioscorea cayenensis- rotundata were } \\
\text { initiated on free-hormone MS medium and were micropropagated each four months } \\
\text { during five subcultures. DNA was extracted both from mother plant and plantlets provided } \\
\text { from the subcultures for each accession and was exhibited Random Amplified } \\
\text { Polymorphic DNA (RAPD) analysis using four selected primers to detect somaclonal } \\
\text { variation. No phenotypic variation was observed during the fifth subcultures. From the } \\
\text { RAPD analysis of both mother plants and in vitro plantlets, no significant variation of } \\
\text { DNA profiles was observed with the highest of the coefficient of similarity ( } 85 \% \text { to } \\
100 \% \text { ) for all accessions, thus ensuring the genetic stability of the plants and regeneration } \\
\text { of true to type plants for at least five subcultures }\end{array}$} & $\begin{array}{l}\text { Accepted: } 22 \text { March } 2017 \\
\text { Available Online: 06 April } 2017\end{array}$ \\
\hline & Keywords \\
\hline & Dioscorea spp. \\
\hline & Genotype fidelity \\
\hline & In vitro genebanks \\
\hline & RAPD \\
\hline & Subcultures \\
\hline & \\
\hline
\end{tabular}

\section{Introduction}

In term of the conservation of the diversity of species, genebanks are very important because they offer important traits of interest for breeding in germplasm enhancement through variety development (Spooner et al., 2005). In traditional system, yam germplasm are maintained in field genebanks as living collections because genotypes are either highly sterile, produce heterogeneous seeds, or possess tubers which have poor storability (Zoundjihekpon, 1993). Field maintenance involves high costs and risks of genetic erosion due to pest/pathogen attacks and natural disasters (Houedjissin and Koudande, 2010). Girma et al. (2012) reported that in the field collection, many mixed individuals /mismatched of number of accessions of yam were found causing by Human errors such as mislabeling, loss and fade of label(s), material mix during regeneration process and other field gene bank management problems. Despite in-situ conservation is preferentially applied for genetic resources for several woody species and cultivated species, ex-situ conservation remain the challenge for maintenance of the non-orthodox and vegetative propagated species (Engelmann, 2010). Since, several studies reported that cells and organs in vitro culture techniques are successfully used for 
conservation of yam germplasm (Engelmann, 1991; Ahanhanzo et al., 2003; Mandal and Sonali, 2007; Agbidinoukoun et al., 2013). Those techniques offer more advantages such as rapid multiplication of explants, require lower area, free diseases plantlets production.

In Benin, propagation of yam through in vitro techniques has been reported by recent researches using different explants sources as well as regeneration pathways (Ahanhanzo et al., 2010 and 2012). This propagation is based on vegetative cell totipotency and gets through subcultures which frequency is four times per year. However, available literatures reported that high number of subculture may lead to somaclonal or epigenetic variations in the micropropagated plantlets (Lakshmanan et al., 2007; Peyvandi et al., 2009). Now, in conservation term, the fundamental principle is to guarantee genotype stability. Therefore, it is necessary to establish genetic uniformity of micropropagated plantlets. Somaclonal variation is defined as genetic and phenotypic variation among clonally propagated plants of a single donor clone (Larkin, 1987). According to recent reports, somaclonal variations were detected among micropropagated plantlets in many taxa at levels such as phenotypic and cytological (Podwyszyńska, 2005; Zayova et al., 2010), biochemical and molecular (Soundararajan and Karrunakaran, 2010; Kanungo et al., 2012; Senapati et al., 2012; Saha et al., 2012).

Molecular markers are widely used to detect somaclonal variation at the DNA level of the available techniques such as isozyme, AFLP, RFLP, RAPD and ISSR. Moreover, RAPD (Random Amplified Polymorphic DNA) markers have been shown to be useful in assessing intra-specific or inter-specific genetic variability in many crop plant species because; large number of samples can be quickly and economically analyzed by using only micro-quantities materiel. In addition, the DNA amplicons are independent from ontogenic expression and many genomic regions can be sampled with a potentially unlimited number of markers changes in the RAPD pattern may result from the loss/gain of a primer annealing provoked by point mutations or by the insertion or deletion of sequences or transposition elements (Kaeppler et al., 2000). On top of that, RAPD markers have been already used for cultivar identification in a wide range of yams species (Dansi et al., 2000; Zannou et al., 2009). Up to now, the genetic stability of the in vitro subcultures of yam accessions is not yet tested. The purpose of this work was to investigate the influence of number of subcultures on the genotype stability for yam accessions plantlets using RAPD markers.

\section{Materials and methods}

\section{Plant materiel}

The plant material used was represented by six Dioscorea accessions (Ala, Baghi, Kogan, Kokoro, Tankpanou and Sossou.) belonging to the complex Dioscorea cayenensis-rotundata, which were grown aseptically in the screen house.

\section{Initiation and subculturing}

Axillary buds for each accession were taken from screen house- planted germplasm six weeks after planting. The cuttings were sterilized with $0,1 \mathrm{mg} / \mathrm{l}$ of mercuric chloride in sterile condition over laminar flow prior their culture in free-hormone MS medium (Murashige and Skoog, 1962). Four months after culture, the microcuttings were taken from plantlets for each accession and subcultured in the same medium. Five subcultures were made in the containers with five microcuttings. For each accession, ten containers were used. Fig. 1 shows the plantlets provided to the third subculture (F3).

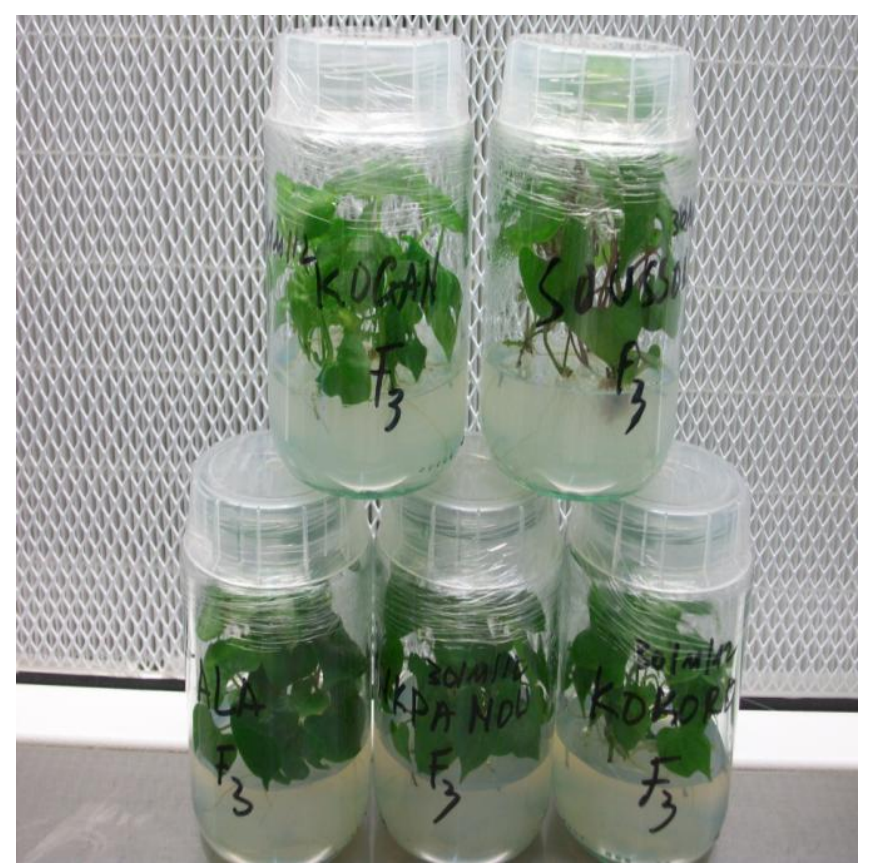

Fig. 1: Yam plantlets regenerated on free-hormone MS medium at the third subculture for five accessions tested (Kogan, Soussou, Ala, Tankpanou and Kokoro). 


\section{DNA Extraction}

Genomic DNA from young leaves of mother plants produced in screen house and their plantlets (Fig. 1) was extracted by Mixel Alkyl Triméthyl Ammonium Bromide (MATAB) procedure (Gawel and Jarret, 1991) previously using for yams by Agbangla et al. (2002). DNA extraction process successful was checked with electrophoresis on $0.8 \%$ agarose gel. Seven arbitrary decamer RAPD primers (Table 1) which have been used successfully on Musa and yam species (Lakshmanan et al., 2007; Zannou et al., 2009) were used for Polymerase Chain Reaction (PCR) for DNA amplification. DNA finger printing profiles were compared to evaluate clonal fidelity and genetic stability.

Table 1. List and sequence of the 10-base nucleotide primers used for the RAPD analysis.

\begin{tabular}{ll}
\hline Markers code & Primers sequences \\
\hline OPA02 & 5'- TGCCGAGCTG- 3' \\
OPA08 & 5'- GTGACGTAGG- 3' \\
OPA18 & 5'- AGGTGACCGT- 3' \\
OPB04 & 5'- GGACTGGAGT- 3' \\
OPB05 & 5'- TGCGCCCTTC- 3' \\
OPB08 & 5'- GTCCACACGG- 3' \\
OPN-08 & 5'- ACCTCAGCTC- 3' \\
\hline
\end{tabular}

\section{PCR Amplification}

Amplification was performed in $25 \mu \mathrm{L}$ using PCR mixture of consisting of $2.5 \mu \mathrm{L} 10 \mathrm{X}$ buffer, $1 \mu \mathrm{L}$ dNTPs, $0.25 \mu \mathrm{L}$ Taq polymerase, $3 \mu \mathrm{L}$ DNA, $7.0 \mu \mathrm{L}$ primer, $0.75 \mu \mathrm{L} \mathrm{MgCl} 2$ and $10.5 \mu \mathrm{L}$ MiliQ water. The PCR reaction conditions were: preheating for $5 \mathrm{~min}$ at $95^{\circ} \mathrm{C} ; 43$ cycles of $1 \mathrm{~min}$ at $94^{\circ} \mathrm{C}$ for denaturation, $1 \mathrm{~min}$ at $55^{\circ} \mathrm{C}$ for hybridation and $1 \mathrm{~min}$ at $72^{\circ} \mathrm{C}$ for elongation which was completed by a final extension of $10 \mathrm{~min}$ at $72^{\circ} \mathrm{C}$. After amplification, the PCR product was resolved by electrophoresis in $2.5 \%$ agarose gel and stained with ethidium bromide $(0.5 \mu \mathrm{g} / \mathrm{ml})$. The bands were visualized under UV light and photographed using the UV Transilluminator equipment (UVP, LLC Upland, $\mathrm{CA})$. All the PCR reaction was repeated twice.

\section{Data analysis}

The software Microsoft Office Excel 2010 has been used for statistical processing of the data. For the growth parameters, five plantlets of each accession were used to calculate the means of number of leaves and roots and Student, Newman and Keuls' test was used to classify these means using R software.

According to DNA analysis, the amplified DNA fragments detected in each accession were scored for presence (1) or absence (0). A data matrix was prepared for different analyses. A dendrogram was then constructed based on the similarity matrix data using the UPGMA (Unweighted Pair-Group Method using Arithmetic Averages) cluster analysis of NTSYS 2.21f (Rohlf, 2000). The similarity between mother plants and their plantlets was investigated by an Analysis of the coefficient of similarity of Jacquard (1908).

\section{Results}

\section{Phenotypic observation of plantlets after five consecutive subcultures}

For each accession the number of leaves has not varied statistically at $\mathrm{p}=0.05$ during the five subcultures tested (Table 2). The high number of leaves was produced by the accession Kogan (5.6) while the lowest was obtained by accessions Kokoro and Tankpanou (3.4). No significant variation was observed according to roots development through the five subcultures for each accession (Table 3). The accession Soussou produced more roots than others accessions (5.6) and the accession Kogan the lowest (2.4).

Table 2. Means number of leaves of accessions for the five subcultures tested.

\begin{tabular}{llllll}
\hline Accessions & $\mathbf{1}^{\text {st }}$ Subculture & $\mathbf{2}^{\text {nd }}$ Subculture & $\mathbf{3}^{\text {rd }}$ Subculture & $\mathbf{4}^{\text {th }}$ Subculture & $\mathbf{5}^{\text {th }}$ Subculture \\
\hline Ala & $4.8 \mathrm{a}$ & $4.6 \mathrm{a}$ & $4.6 \mathrm{a}$ & $4.8 \mathrm{a}$ & $4.6 \mathrm{a}$ \\
Bagri & $4.6 \mathrm{a}$ & $4.4 \mathrm{a}$ & $4.4 \mathrm{a}$ & $4.4 \mathrm{a}$ & $4.8 \mathrm{a}$ \\
Kogan & $5.4 \mathrm{a}$ & $5.6 \mathrm{a}$ & $5.4 \mathrm{a}$ & $5.2 \mathrm{a}$ & $5.6 \mathrm{a}$ \\
Kokoro & $3.6 \mathrm{a}$ & $4.0 \mathrm{a}$ & $3.4 \mathrm{a}$ & $3.8 \mathrm{a}$ & $3.6 \mathrm{a}$ \\
Sossou & $4.6 \mathrm{a}$ & $4.6 \mathrm{a}$ & $4.2 \mathrm{a}$ & $4.0 \mathrm{a}$ & $4.6 \mathrm{a}$ \\
Tankpanou & $3.6 \mathrm{a}$ & $3.6 \mathrm{a}$ & $3.8 \mathrm{a}$ & $3.6 \mathrm{a}$ & $3.4 \mathrm{a}$ \\
\hline
\end{tabular}

Means with the same letter are not significantly different. 
Table 3. Means number of roots of accessions for the five subcultures tested.

\begin{tabular}{llllll}
\hline Accessions & $\mathbf{1}^{\text {st }}$ Subculture & $\mathbf{2}^{\text {nd }}$ Subculture & $\mathbf{3}^{\text {rd }}$ Subculture & $\mathbf{4}^{\text {th }}$ Subculture & $\mathbf{5}^{\text {th }}$ Subculture \\
\hline Ala & $4.0 \mathrm{a}$ & $3.4 \mathrm{a}$ & $3.6 \mathrm{a}$ & $3.4 \mathrm{a}$ & $3.2 \mathrm{a}$ \\
Bagri & $4.4 \mathrm{a}$ & $4.6 \mathrm{a}$ & $4.6 \mathrm{a}$ & $4.8 \mathrm{a}$ & $4.6 \mathrm{a}$ \\
Kogan & $2.6 \mathrm{a}$ & $2.8 \mathrm{a}$ & $2.6 \mathrm{a}$ & $2.4 \mathrm{a}$ & $2.6 \mathrm{a}$ \\
Kokoro & $3.6 \mathrm{a}$ & $3.6 \mathrm{a}$ & $3.4 \mathrm{a}$ & $3.4 \mathrm{a}$ & $3.6 \mathrm{a}$ \\
Sossou & $5.4 \mathrm{a}$ & $5.4 \mathrm{a}$ & $5.6 \mathrm{a}$ & $5.4 \mathrm{a}$ & $5.6 \mathrm{a}$ \\
Tankpanou & $4.6 \mathrm{a}$ & $4.6 \mathrm{a}$ & $4.6 \mathrm{a}$ & $4.8 \mathrm{a}$ & $4.6 \mathrm{a}$ \\
\hline
\end{tabular}

Means with the same letter are not significantly different

Shoots phenotype obtained from accession Ala through the five consecutive subcultures indicated that no difference was noted on the plantlets morphology
(Fig. 2). The morphology of the plantlets providing to the others accessions has also presented no variation during the five subcultures tested.

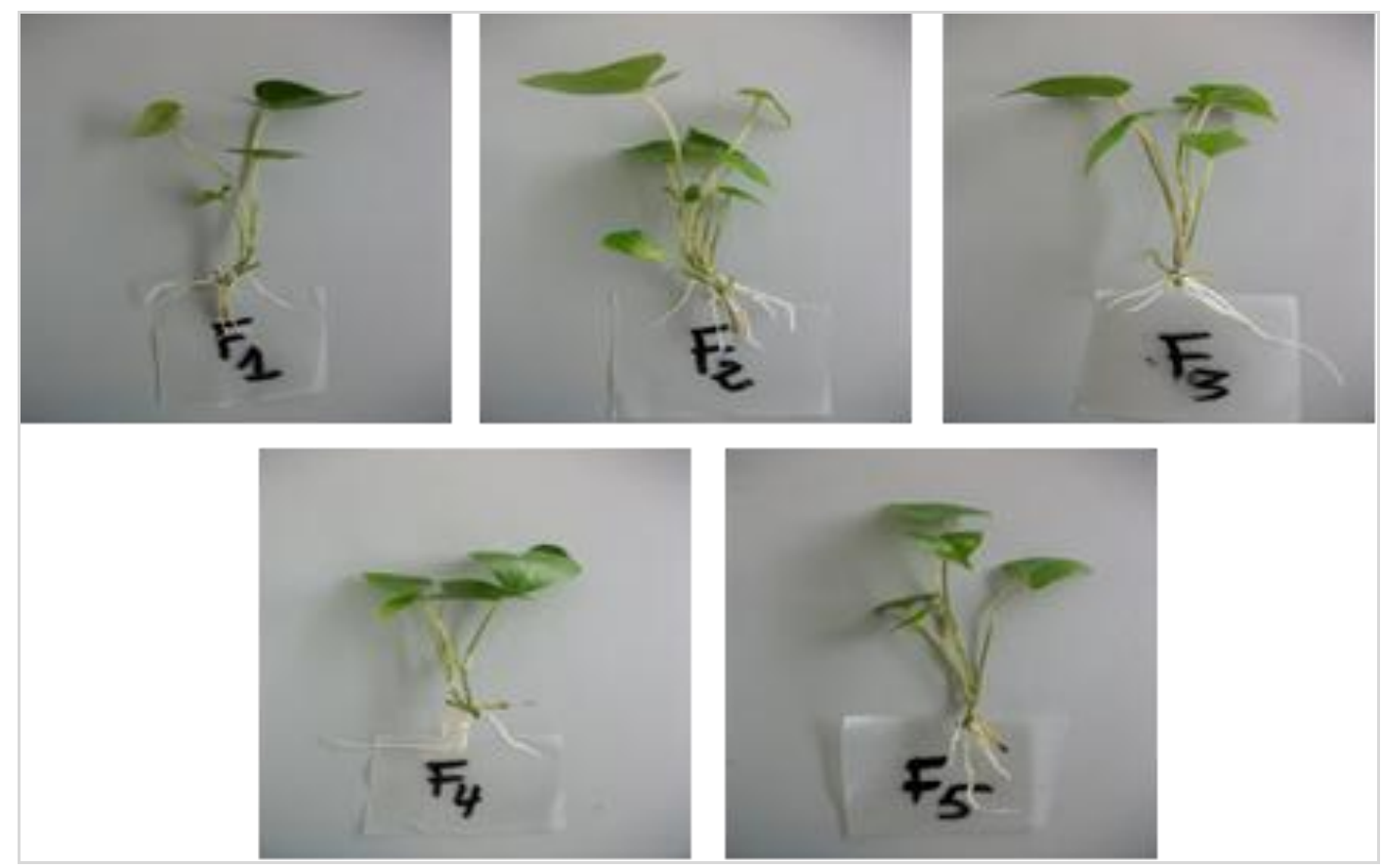

Fig. 2: Morphology of plantlets of accession Ala during five consecutive subcultures.

\section{Comparison of DNA from mother plants and their plantlets}

The electrophoresis profile of DNA of mother plants and their plantlets generated by the marker OPN08 for each accession through the five subcultures were presented in Fig. 3. From the seven markers tested, four of them have been amplified (OPA02, OPA18, OPB05 and OPN08). The profile revealed the presence of different DNA bands witch varied for the six accessions. However, we noted the presence one band of $300 \mathrm{pb}$ from the majority of the accessions from the mother plants and their plantlets. However, this band was absent for almost of the accessions from the fourth subculture. We also noted the absence of $300 \mathrm{pb}$ amplicon in the plantlets belonging to the accessions Kokoro (subcultures 3 and 5), Tankpanou (subcultures 2, 3 and 4) and Sossou (subcultures 4 and 5).

The dendrogram presented on Fig. 4 indicated that for all markers tested, the accession Ala has generated two groups. The first group was constituted by the mother plant and the plantlets derived from the second subculture while the plantlets obtained with the third and fifth subcultures formed the second group. However, the coefficient of similarity of Jacquard (86\%) indicated the highest similarity between mother plant and their plantlets. 


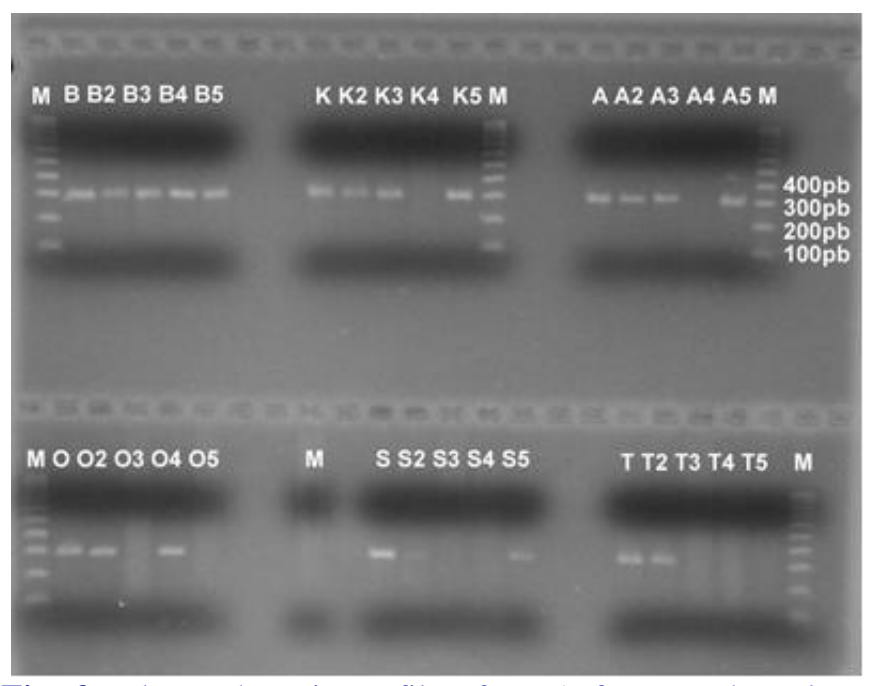

Fig. 3: Electrophoresis profile of DNA from mother plants and their plantlets in $2.5 \%$ agarose gel generated by the marker OPN08. The letters A, B, K, O, S, and T indicate the mother plant of accessions Ala, Baghi, kogan, Kokoro, Soussou and Tankpanou respectively. For each accession, the number ranging to 2 for 5 indicate the second to the fifth subcultures. $\mathrm{M}=$ Ladder marker.
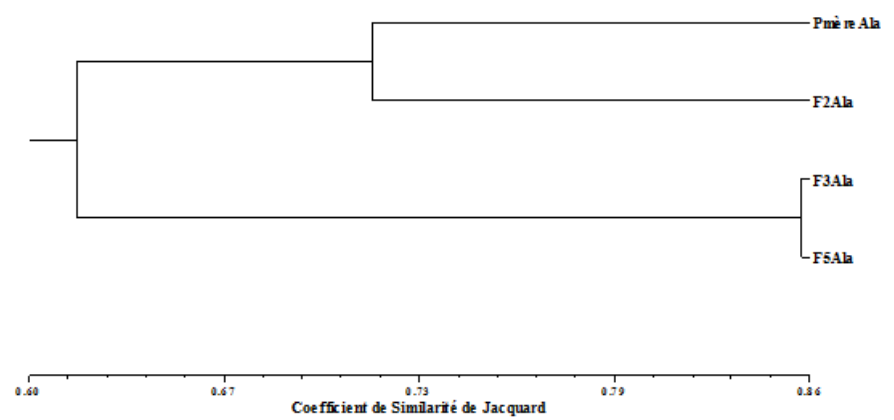

Fig. 4: Dendrogram of accession Ala.
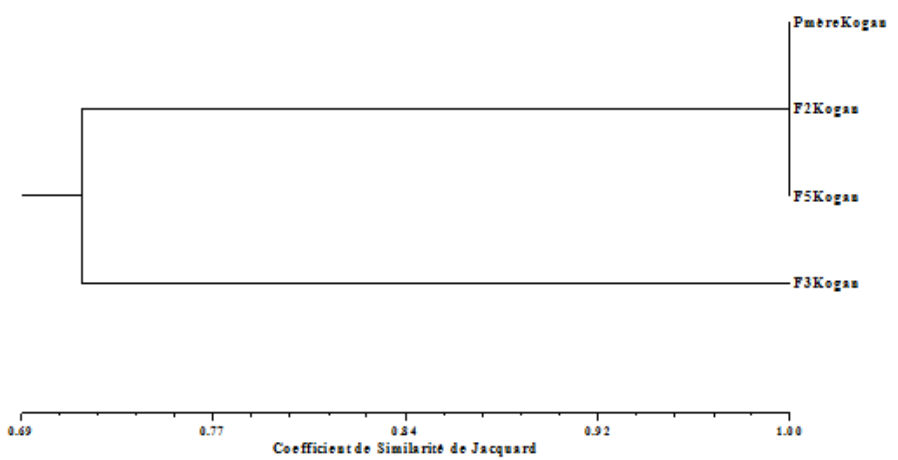

Fig. 5: Dendrogram of accession Kogan.

According to the Fig. 5, two groups were also generated with the accession Kogan. The first one grouped the mother plant and the plantlets regenerated by the second and the fifth subcultures. Only the shoots provided to the third subculture formed the second group. The coefficient of similarity of Jacquard (100\%) showed no difference between the genotype of the plantlets and their mother plant. The others accessions dendrograms (Baghi, Kokoro, and Soussou) were similar to those presented by the accession Kogan.

\section{Discussion}

Current studies have demonstrated that the plantlets regenerated through in vitro tissue culture were suggested to different types of stress which could involve phenotypic or genotypic variations frequently caused by callus regeneration, somatic embryogenesis and the number of subcultures. All of those variations were known as somaclonal variations (Larkin and Scowcroft, 1981). Various source should explain somaclonal variations such as the genotype, the type of explants, the culture duration, the number of subcultures (Peyvandi et al., 2009 and 2010), the media components particularly the hormonal doses and their combinations (Karp, 1994).

In this experiment, the medium was free hormone in order to against their influence on the plantlets genotypes and to be sure that when somaclonal variations will be noted, they should be leading to the number of subcultures. In fact, subculture is the main factor to be controlled because in term of conservation, the fundamental principle is to guarantee genotype stability. The present results revealed no phenotypic variation between plantlets of the six accessions tested suggesting that the five subcultures have no incidence on the phenotype of plants. The high presence of $300 \mathrm{pb}$ band in both the plantlets and their donors (mother plants) in all tested accessions using RAPD markers could be an indicator for genotypic stability of plantlets along the five subcultures.

Despite the different groups showed by the dendrogram for each accession, the coefficient of similarity of Jacquard was up to $85 \%$ for all accessions tested indicating the highest similarity between plantlets and their mother plants respectively. Our result suggests that at the level of five subcultures spaced to four months each, the number of subcultures has not influenced the genotype of plants. This result supports Ahanhanzo et al. (2012) who reported that the in vitro tissue culture has never affected the genotype of plantlets at the first subculture for the same accessions. The presence of different groups should be explained by the epigenetic 
phenomena which are not transmissible to the descendant or the subsequent corrections of the modified DNA sequence. In addition, Kaeppler et al. (2000) noted that the highly variable among regenerated plants and their progeny has frequently caused by the DNA methylation patterns. Although the RAPD markers are widely used for the somaclonal variations diagnostic (Govinden Soulange et al., 2007; Kanungo et al., 2012; Senapati et al., 2012; Saha et al., 2012), they have nowadays been contested because of their nonreproducibility.

In conclusion, the results of the present study demonstrate that most of the accessions of Dioscorea spp. maintained in free-hormone MS medium have no phenotypic variations. For the genotype stability assessment, RAPD markers revealed genotypic fidelity on mother plants and their progeny within at least five subcultures. In further, we suggest the used of others markers to validate the present result.

\section{Conflict of interest statement}

Authors declare that they have no conflict of interest.

\section{Acknowledgement}

The authors thank CBRSI (Centre Béninois de Recherche Scientifique et d'Innovation) for supporting the prospection and SEDAH Paulin for his technical assistance during the molecular analysis. We also thank the managers of INRAB (Institut National de Recherche Agronomique du Benin) for their assistance during the prospection and all the Famers for their fool collaboration.

\section{References}

Agbangla, C., Ahanhanzo, C., Tostain, S., Dansi, A., Daïnou, O., 2002. Evaluation de la diversité génétique par RAPD d'un échantillon de Dioscorea alata d'une région du Bénin, la sous-préfecture de Savè. J. Rech. Sci. Uni. Lomè (Togo). 6(1), 197-202.

Agbidinoukoun, A., Ahanhanzo, C., AdoukonouSagbadja, H., Adjassa, M., Agassounon DjikpoTchibozo, M., Agbangla, C., 2013. Impact of osmotic dehydration on the encapsulated apices survival of two yams (Dioscorea spp.) genotypes from Benin. J. Appl. Biosci. 65, 4999-5007.

Ahanhanzo, C., Agbangla, C., Toukourou, F., Dansi, A., Daïnou, O., 2003. Microbouturage et conservation in vitro des ressources génétiques d'igname cultivées au Bénin. Ann. Sci. Agron. Bénin. 6(1), 89-102.

Ahanhanzo, C., Agbidinoukoun, A., Agbangla, C., Adjanohoun, A., Kumulungui B.S., Ondo Ovono, P., Ndong Nzang, R.A., Souza, A.P., 2012. Capacité morphogénétique in vitro de quelques accessions d'ignames du complexe Dioscorea cayenensis / D. rotundata cultivées au Bénin et évaluation de la qualité d'ADN du matériel régénéré. Rev. Ivoir. Sci. Technol. 20, 68-86.

Ahanhanzo, C., Gandonou, Ch.B., Agbidinoukoun, A., Dansi, A., Agbangla, C., 2010. Effect of two cytokinines in combination with acetic acid naphthalene on yams (Dioscorea spp.) genotypes' response to in vitro morphogenesis. Afr. J. Biotechnol. 9(51), 8837-8843.

Dansi, A., Mignouna, H.D., Zoundjihekpon, J., Sangare, A., Ahoussou, N., Asiedu, R., 2000. Identification of some Benin Republic's Guinea yam (Dioscorea cayenensis/ Dioscorea rotundata complex) cultivars using Randomly Amplified Polymorphic DNA. Genetic Resour. Crop Evol. 47, 619-625.

Engelmann, F., 1991. In vitro conservation of tropical plant germplasm - a review. Euphytica. 57, 227-243.

Engelmann, F., 2010. Use of biotechnologies for the conservation of plant biodiversity. In Vitro Cell. Dev. Biol. -Plant. 47(1), 5-16.

Gawel, N.J., Jarret, R.L., 1991. A modified CTAB in MATAB: DNA extraction procedure for Musa and Ipomoea. Plant. Mol. 9, 262-266.

Girma, G., Korie, S., Dumet, D., Franco, J., 2012. Improvement of accession distinctiveness as an added value to the global worth of the yam (Dioscorea spp.) genebank. Int. J. Conserv. Sci. 3(3), 199-206.

Govinden Soulange, J., Ranghoo-Sanmukhiya, V.M., Seeburrun, S.D., 2007. Tissue culture and RAPD analysis of Cinnamomum camphora and Cinnamomum verum. Biotechnology. 6(2), 239-244.

Houedjissin, R.C., Koudande, D.O., 2010. Etat des lieux de la recherche sur l'igname au Bénin, rapport final. $55 \mathrm{p}$.

Jacquard, P., 1908. Nouvelles recherches sur la distribution. Florale. Bull. Soc. Vaud. Sci. Nat. 44, 223-247.

Kaeppler, S.M., Kaeppler, H.F., Rhee, Y., 2000. Epigenetic aspects of somaclonal variation in plants. Plant Mol. Biol. 43, 179-188.

Kanungo, S., Pradhan, C., Das, A.B., 2012. In vitro microrhizomes induction and genetic stability of a 
medicinal plant Acorus calamus L. towards germplasm conservation through synthetic seed production. Analele Univ. Oradea - Fasc. Biol. 19(2), 146-153.

Karp, A., 1994. Origins, causes and uses of variation in plant tissue culture. In: Plant Cell and Tissue Culture (Eds.: Vasil, I.K., Thorpe, T. A.). Part A. Springer Netherlands. pp.139-151.

Lakshmanan, V., Sreedhar, R.V., Bhagyalakshmi, N., 2007. Molecular analysis of genetic stability in longterm micropropagated shoots of banana using RAPD and ISSR markers. E-J. Biotechnol. 10(1), 07173458.

Larkin, P.J., Scowcroft, W.R., 1981. Somaclonal variation - a novel source of variability from cell cultures for plant improvement. Theor. Appl. Genet. 60, 197-214.

Larkin, P.J., 1987. Somaclonal variation: history, method, and meaning. Iowa State J. 61, 393- 434.

Mandal, B.B., Sonali, D.S., 2007. Cryopreservation of in vitro shoot tips of Dioscorea deltoidea Wall., an endangered medicinal plant: effect of cryogenic procedure and storage duration. Cryo Lett. 28(6), 461-470.

Murashige, T., Skoog, E., 1962. A revised medium for rapid growth and bioassays with tobacco tissue cultures. Physiol. Plant. 15, 473-497.

Peyvandi, M., Nemat Farahzadi, H., Arbabian, S., Noormohammadi, Z., Hosseini-Mazinani, M., 2010. Somaclonal variation among somatic-embryo derived plants of Olea europaea L. cv. "Kroneiki". J. Sci. Islamic Republic of Iran. 21(1), 7-14.

Peyvandi, M., Noormohammadi, Z., Banihashemi, O., Farahani, F., Majid, A., Hosseini-Mazinani, M. Sheidai, M., 2009. Molecular analysis of genetic stability in long-term micropropagated shoots of Olea europaea L. (cv. Dezful). Asian J. Plant Sci.
8(2), 146-152.

Podwyszyńska, M., 2005. Somaclonal variation in micropropagated tulips based on phenotype observation. J. Fruit Ornam. Plant Res.13, 109-122.

Rohlf, F.J., 2000. NTSYS-pc Numerical Taxonomy and Multivariate Analysis System, vs 2.20e. Exeter Publication, New York, USA.

Saha, S., Kader, A., Sengupta, C., Ghosh, P., 2012. In Vitro Propagation of Ocimum gratissimum L. (Lamiaceae) and Its Evaluation of Genetic Fidelity Using RAPD Marker. Amer. J. Plant Sci. 3, 64-74.

Senapati, S.K., Aparajita, S., Rout, G.R., 2012. An assessment of genetic fidelity of in vitro grown plantlets of rose (Rosa hybrida) through molecular markers. Afr. J. Biotechnol. 11(100), 16532-16538.

Soundararajan, T., Karrunakaran, C.M., 2010. Micropropagation of Nerium oleander through the immature pods. J. Agric. Sci. 2(2), 182-193.

Spooner, D., Treuren, R., Vicente, M.C., 2005. Molecular markers for genebank management, IPGRI Technical Bulletin, No. 10, International Plant Genetic Resources Institute, Rome.

Zannou, A., Agbicodo, E., Zoundjihékpon, J., Struik, P.C., Ahanchédé, A., Kossou, D.K., Sanni, A., 2009. Genetic variability in yam cultivars from the Guinea-Sudan zone of Benin assessed by random amplified polymorphic DNA. Afr. J. Biotechnol. 8(1), 026-036.

Zayova, E., Vassilevska-Ivanova, R., Kraptchev, B., Stoeva, D., 2010. Somaclonal variations through indirect organogenesis in eggplant (Solanum melongena L.). Biol. Diver. Conserv. 3(3), 1-5.

Zoundjihekpon, J., 1993. Biologie de la reproduction et génétique des ignames cultivées de l'Afrique de l'Ouest, Dioscorea cayenensis-D. rotundata. Thèse de Docteur ès Sciences Naturelles. N) d'ordre 194Université nationale de Côte d'Ivoire. 306p.

\section{How to cite this article:}

Agbidinoukoun, A., Missihoun, A. A., Akonde, P., Sagbadja, H.A., Agbangla, C., Ahanhanzo, C., 2017. Assessment for the incidence of number of subcultures on genotype stability for in vitro plantlets of yam (Dioscorea spp.) using RAPD markers. Int. J. Curr. Res. Biosci. Plant Biol. 4(4), 32-38. doi: https://doi.org/10.20546/ijcrbp.2017.404.006 